\title{
Islam, politiek en burgerschap: hoe verhouden die zich tot elkaar?*
}

\author{
Roel Meijer
}

In dit artikel zal ik aan de hand van een aantal prominente hedendaagse islamitisch denkers de relatie tussen religie, politiek en burgerschap uiteenzetten. ${ }^{1}$ Daarbij zijn drie stromingen relevant: het islamisme, dat van de islam in eerste instantie een moderne politieke ideologie heeft gemaakt; het salafisme, de fundamentalistische islam die terugkeert naar de bronnen van de islam en de moderniteit ondergeschikt maakt aan de islamitische leer; en ten slotte het modernisme, dat een synthese zoekt tussen de islam en de moderniteit en een islamitisch humanisme voorstaat. Ik zal me in de eerste plaats beperken tot Arabische stromingen, al zijn de drie stromingen in de gehele islamitische wereld terug te vinden. In de tweede plaats zal ik duidelijk maken op welke manier de ideeën van deze islamitische stromingen het islamitische discours in Nederland hebben beïnvloed. ${ }^{2}$

Allereerst is het belangrijk een definitie te geven van wat ik onder politiek versta. Hiervoor zal ik de definities van Chantal Mouffe en Claude Lefort hanteren. ${ }^{3}$ Hun belangrijkste stelling is dat de maatschappij altijd beheerst wordt door sociaaleconomische tegenstellingen en dat de politiek die tegenstellingen met respect voor de tegenstander op een vreedzame manier moet oplossen. Dit kan samengaan met macht, maar mag niet gepaard gaan met geweld. Voorwaarde voor het beoefenen van politiek is dat er een neutrale ruimte bestaat waarin het politieke debat kan plaatsvinden.

Naast deze definitie hanteer ik het door de politiek filosofen Sheldon Wolin en Alan Ryan ontwikkelde paradoxale idee dat gedurende de hele geschiedenis de politiek juist conflicten probeert te vermijden en dit doet door politieke tegenstellingen onder andere noemers te plaatsen. ${ }^{4} \mathrm{Zij}$ noemen deze praktijk het 'absorberen' (absorption) van de politiek. Dit kan bijvoorbeeld gebeuren door politieke aangelegenheden te herformuleren als technocratische kwesties. In dat geval ont-

* Dit artikel is grotendeels gebaseerd op mijn hoofdstuk 'The Political, Politics and the Citizenship in Modern Islam', in: N. Butenschøn \& R. Meijer (red.), The Middle East in Transition: The Centrality of Citizenship, 2018, p. 179-202.

1 Dit artikel is grotendeels gebaseerd op mijn hoofdstuk 'The Political, Politics and the Citizenship in Modern Islam', in: N. Butenschøn \& R. Meijer (red.), The Middle East in Transition: The Centrality of Citizenship, 2018, p. 179-202.

2 Om makkelijker de vergelijking met het Midden-Oosten te maken vergelijk ik deze drie stromingen, terwijl er veel meer stromingen binnen de islam in Nederland bestaan.

3 C. Lefort, 'La logique totalitaire', in: C. Lefort, L'invention démocratique, Parijs 1981, p. 85-106; C. Mouffe, The Return of the Political, New York 1993, p. 4.

4 S.S. Wolin, Politics and Vision: Continuity and Innovation in Western Political Thought, Princeton 2004; A. Ryan, On Politics: A History of Political Thought from Herodotus to the Present, Londen 2012 . 
wijken 'experts' de politieke problemen door die te verpakken in technocratisch jargon en onder te brengen en te 'verdelen' (defusion) in technocratische maatregelen waardoor de politieke inhoud onzichtbaar wordt.

Een ander voorbeeld van deze antipolitiek, wat de Nederlandse politiek filosoof Luuk van Middelaar 'politicide' noemt, is het marxisme. ${ }^{5}$ Deze ideologie reduceert politieke tegenstellingen tot klassenstrijd en zoekt de oplossing van de economische tegenstellingen in een klasseloze maatschappij. Religie is natuurlijk hier ook een goed voorbeeld van: de politiek wordt geabsorbeerd door de religie, die de werkelijke tegenstellingen in de maatschappij verdoezelt en diffuus maakt in een harmoniemodel van naastenliefde. De kritiek is dat religie de politiek naar zich toetrekt, terwijl zij daarvoor niet uitgerust is en niet de terminologie noch de middelen heeft om politieke en economische tegenstellingen daadwerkelijk op te lossen. Er vindt dan eigenlijk alleen een verschuiving plaats: politieke problemen worden religieuze problemen, wat een verplaatsing inhoudt naar een 'domein' (religie) dat zich vooral bezighoudt met de moraal en ethische problemen.

Voorwaarde voor het ontstaan van de erkenning van de politiek door alle betrokken partijen als een zelfstandig proces met een eigen logica is een mate van secularisering die gescheiden 'velden' van kennis en praktijk heeft voortgebracht. Tijdens dat seculariseringsproces is een economisch, sociaal, juridisch, wetenschappelijk en religieus domein (veld) ontstaan, elk met zijn eigen wetmatigheden en specialisten. Dit is een universeel verschijnsel dat onderdeel is van het moderniseringsproces dat zich inmiddels in alle regio's van de wereld heeft verspreid en onderdeel is van globalisering. ${ }^{6}$ Deze ontwikkeling sluit echter niet uit dat de verschillende domeinen elkaar proberen te overheersen. Zo maakt Michael Walzer zich vooral zorgen over de hegemonie die de (neoliberale) economie probeert te verkrijgen over de politiek in de Verenigde Staten, terwijl andere politieke filosofen en politici deze zorg hebben over de religie. Volgens Walzer is het de kunst 'de scheidingsmuren' (walls of separation) tussen de domeinen in stand houden, om te voorkomen dat er een totalitaire staat ontstaat waarbij een bepaald veld - bijvoorbeeld economie, politiek of religie - andere velden overheerst. In feite draait volgens Walzer het liberalisme niet zozeer om het individualisme, maar om het verdedigen van deze scheidingsmuren tussen economie, religie en wetenschap. ${ }^{7}$ Voor religieus geïnspireerde politici betekent dit niet dat ze hun overtuigingen thuis moeten laten, wat onmogelijk is; wel betekent het dat ze die in algemene politieke termen moeten vertalen.

Claude Lefort gaat nog een stapje verder en stelt dat in de moderniteit alle domeinen een ongecontroleerd eigen leven zijn gaan leiden: 'De moderne samenleving lijkt mij met een radicale onbepaaldheid te worden geconfronteerd; de samenleving die het theater van een onbeheersbaar avontuur is geworden.' ${ }^{8}$ Zelfs de politiek is 'radicaal onbepaald' geworden, een vacuüm dat telkens opgevuld moet wor-

5 Zie vooral het uiterst leesbare boek van L. van Middelaar, Politicide: De moord op de politiek in de Franse filosofie, Brussel 2011. Dit boek geeft een uitstekend inzicht hoe de politiek door bepaalde ideologieën om zeep wordt geholpen.

$6 \quad$ K. Dobbelaere, Secularization: An Analysis at Three Levels, Brussel 2002.

7 M. Walzer, Thinking Politically: Essays in Political Theory, New Haven 2007.

8 C. Lefort, Wat is politiek? Amsterdam 2016, p. 51. 
den door nieuwe ideeën en stromingen, maar dat permanent instabiel is en alleen door een continu debat in stand kan worden gehouden. Pogingen die onbepaaldheid te onderdrukken en alle 'velden' onder controle te krijgen leiden tot totalitarisme. ${ }^{9}$ Hoewel deze schrijvers het niet hebben over burgerschap, kan men uit hun denkbeelden concluderen dat het hebben van politieke rechten als burger niet mogelijk is zonder het bestaan van een onafhankelijk politiek domein waarin de burger deelneemt aan dat continue debat, of in ieder geval dat actief of passief intact houdt. Dit kan alleen als iedereen op gelijke wijze daar toegang toe heeft en afwijkende meningen worden toegestaan en niet gecensureerd worden door ideologieën of religieuze opvattingen.

Het grote probleem van een aantal moderne islamitische stromingen is dat ze geen eigen dynamiek aan de politiek toekennen en ook nog eens alle andere terreinen aan religie ondergeschikt willen maken. Dit streven is verwoord in de leuze 'islam is een totaal systeem' ('nizam kamil'). ${ }^{10}$ Voor de politiek heeft dit de consequentie dat het ondergeschikt gemaakt wordt aan religie en daardoor beheerst wordt door een streng moralisme over wat er eigenlijk moet gebeuren volgens religieuze normen, niet hoe maatschappelijke problemen - economische groei, gelijkheid tussen religies, jongerenproblemen, bevolkingsgroei, werkloosheid, buitenlandse relaties - kunnen worden aangepakt. ${ }^{11}$ Als gevolg van deze 'absorptie' van de politiek door religie en 'diffusie' in religieuze termen wordt een in wezen politiek debat een religieus debat over de positie van de islam en rechten van moslims. Hiermee is niet alleen het debat verplaatst naar een domein waar het niet thuishoort, maar worden de onderliggende problemen moeilijker te analyseren omdat het een identiteitsprobleem is geworden dat in absolute waarheden wordt gevoerd - de islam is Gods woord en niet-moslims moeten dat respecteren. Deze 'afleidingsstrategie' heeft ook gevolgen voor burgerschap, want zonder de erkenning van een onafhankelijk politiek domein is het lastig om politieke rechten te claimen en lid te zijn van een politieke gemeenschap en daarin op gelijke wijze te participeren. Het probleem wordt nog complexer doordat bij religie ook nog eens de waarheidsclaim groter is dan bij de andere velden. Het gevolg is het ontstaan van religieuze bewegingen die de hegemonie willen verkrijgen over de maatschappij, of een quiëtistische, apolitieke strategie ontwikkelen om zich terug te trekken op de eigen gemeenschap en alleen een beperkt burgerschap te ontwikkelen voor de belangen van de 'eigen kring'.

9 Lefort 2016, p. 52.

10 H. al-Banna, 'Da'watuna', in: Majmu'at rasa'il imam shahid Hasan al-Banna ['Onze missie', in: Verzamelde geschiriften van de martelaar Hasan al-Banna), geen datum, geen plaats, p. 16. In het Arabisch wordt dit streven naar totale controle over de politiek, economie en maatschappij shoemoeliyya genoemd.

11 In Nederland wordt door Wilders en andere populistische politici gesteld dat islam een totalitaire ideologie is. Dat is natuurlijk niet juist. Een religie die al eeuwen bestaat, kan geen totalitaire ideologie zijn. Dit neemt niet weg dat de politieke islam (islamisme) en het salafisme totalitaire trekken hebben. Die trekken hebben ze omdat ze modern zijn en uit een autoritaire politieke omgeving komen. Zie S. Vellenga, 'Religieuze orthodoxie als bedreiging. Verschuivingen in het publieke debat', Tijdschrift voor Religie, Recht en Beleid 2011, 2, p. 7-22. 
In het geval van Nederland zien we de verwarring van politiek en religie bijvoorbeeld bij de discriminatie van Marokkaanse jongeren: dat wordt vaak al snel in het kader van de islam bezien ('wij worden gediscrimineerd omdat we moslims zijn'), en religie wordt door hen ook als deel van het antwoord beschouwd (opbouwen van een sterkere moslimidentiteit, islamitische partijen stichten, respect voor de islam eisen), terwijl het probleem heel ergens anders zou kunnen liggen (opleidingsniveau, criminaliteit onder Marokkaanse jongeren, familiestructuren enz.) die helemaal niets met de islam te maken hebben. Het gevolg is een verzwakking van burgerschap en politieke participatie, want de verschuiving van een sociaaleconomisch probleem naar een religieus probleem ondermijnt het gevoel deel uit te maken van de Nederlandse maatschappij en de mogelijkheden een open politieke discussie te voeren over het onderwerp, coalities te sluiten met andere groepen en oplossingen te zoeken. Het is daarom verstandig zo min mogelijk mee te gaan in het identiteitsdiscours.

\section{Islam en politiek}

In tegenstelling tot wat altijd wordt beweerd, heeft er in de praktijk bijna gedurende de gehele geschiedenis van de islam een scheiding bestaan tussen religie en politiek. De twee vielen misschien tijdens het leven van de profeet Mohammed samen, daarna hebben ze een uiterst gecompliceerde relatie gehad. De geestelijken van hun kant hebben vaak een diep wantrouwen gekend tegenover de opportunistische politiek die tot compromissen en corruptie leidt; aan de andere kant hebben politieke leiders weliswaar de legitimatie van hun macht gezocht in islamitische termen, maar in de praktijk hebben ze on-islamitische belastingen geheven en allerlei staatinstellingen in het leven geroepen die niet werden voorzien door de profeet Mohammed en niet gedekt worden door de islamitische wet. ${ }^{12}$ Onder invloed van het Westen werd dit proces in de negentiende eeuw nog eens enorm versterkt. Er bestond dus al een vorm van vergaande secularisering in de premoderne tijd; ook bleef in theorie altijd het ideaal bestaan van een ongedeelde religie. ${ }^{13}$

Het einde van het Osmaanse Rijk en de afschaffing van het kalifaat in 1924 produceerden wat Lefort noemde de 'radicale onbepaaldheid van de politiek'. Het verschil met voorheen was dat nu het imperialistische Westen de grote bedreiging was en de realistische islamitische politieke krachten van het toneel waren verdwenen. Het islamisme als massabeweging maakte van dit vacuüm gebruik door de islam in een politieke ideologie met totalitaire claims te transformeren. Het klassieke voorbeeld is de door Hasan al-Banna in 1928 in Egypte opgerichte Mos-

12 Zie voor de secularisering van islamitisch recht door de macht van de sultan: K. Vikør, Between God and the Sultan: A History of Islamic Law, Londen 2005, p. 185-221; S. Zubaida, Law and Power in the Islamic World, Londen 2003.

13 Volgens de sharia-specialist Wael Hallaq zijn een moderne staat en de uitvoering van sharia niet met elkaar te verenigen, omdat de moderne staat gebaseerd is op macht en sharia een maatschappelijk ethisch systeem is dat in stand werd gehouden door rechtsgeleerden. Zie W. Hallaq, The Impossible State: Islam, Politics and Modernity's Moral Predicament, New York 2013. 
lim Broederschap. De centrale slogans van de beweging geven meteen al aan dat ze de 'scheidingsmuren' die de Osmaanse sultans in praktijk erkenden, neer wilden halen. Haar beroemdste slogans 'Islam is staat en religie' en 'De profeet is onze leider en de Koran onze grondwet' waren gebaseerd op het idee van de islam als 'totaal systeem' dat alle aspecten van het leven dekt en overal antwoord op geeft.

Binnen dit kader werd het moeilijk voor Hasan al-Banna (1906-1949) om democratische principes te ontwikkelen. Het is dan ook niet verwonderlijk dat hij geen concept van politiek als zelfstandig domein ontwikkelde, noch van burgerschap. Het eerste krijgt de betekenis van 'leiding' (irshad), die niet theologisch was, maar wel met religie doordrenkt was en zeer autoritair was. Zo heette het politbureau van de Moslim Broederschap het 'Leidinggevend Bureau' en Hasan al-Banna droeg de titel 'Algemeen Leider'. En hoewel Banna de staat Egypte erkende en zelfs indertijd met de Egyptische koning samenwerkte tegen het seculiere nationalisme, beschouwde hij alleen de leden van de Moslim Broederschap als rechtmatige burgers. Bovendien hadden de leden van de Moslim Broederschap vooral plichten en weinig rechten en dienden ze volgens de Koranische opdracht 'te luisteren en te gehoorzamen', wat in de praktijk betekende dat leden het charismatisch leiderschap van de leider moesten volgen. Hoewel indertijd Egypte een parlementaire democratie kende, verwierp Hasan al-Banna het politieke pluralisme als een aantasting van eenheid die nodig was in de strijd voor de nationale onafhankelijkheidsstrijd tegen het Westen. Partijpolitiek duidde hij aan met de uiterst negatieve term hizbiyya, afgeleid van het Arabische woord hizb (partij), dat volgens hem vooral op verdeeldheid (fitna) zou wijzen. Er is maar één partij, aldus alBanna, namelijk de partij van God (hizballah), in dit geval de Moslim Broederschap. Dat de politiek bij de Moslim Broederschap volledig geabsorbeerd werd door religie, werd nog eens benadrukt door politiek gelijk te stellen aan 'afwijking van de religieuze leer' (inhiraf). De slogan 'Islam is de oplossing', die de Moslims Broederschap vooral tijdens verkiezingen onder Mubarak gebruikte, geeft het populisme van de beweging aan. ${ }^{14}$

Hasan al-Banna werd in 1949 door de Egyptische geheime dienst vermoord. De crisis waarin de organisatie daarna terechtkwam, werd nog verder verdiept door de geestelijke opvolger van Hasan al-Banna, Sayyid Qutb (1906-1966). In zijn geschriften is de politiek volledig verdwenen. Verving Hasan al-Banna de politiek door 'leiding', Sayyid Qutb geeft ruim baan in zijn bekendste boek, Mijlpalen, aan het utopische karakter van de islam door de totale onderwerping aan God te bepleiten: hiervoor introduceerde hij de term hakimiyya. ${ }^{15}$ Op zich zou deze stap burgerschap moeten versterken, in die zin dat de burger zich niet langer onderwerpt aan het autoritaire gezag van de politiestaat van de toenmalige president Nasser, of zelfs aan een islamitische leider als Hasan al-Banna. Maar de keuze die de 'burger' bij Qutb wordt gedwongen te maken is wel erg beperkt, namelijk die

14 Voor een gedetailleerde analyse van de geschriften van Hasan al-Banna: zie mijn eerdergenoemde hoofdstuk, 'The Political, Politics and Citizenship in Modern islam'.

15 S. Qutb, Milestones, uitgegeven door verschillende uitgeverijen. Dit boekje van 120 pagina's is nog steeds populair en vaak het eerste boekje dat jihadi's lezen. 
tussen het voeren van de gewapende, door islam gelegitimeerde, strijd (jihad) tegen het regime, of tegen afvalligheid. Volgens Qutb was de crisis waarin de islam verkeerde in de tijd van het seculiere Arabisch socialisme zo groot dat moslims niets anders overbleef dan zich op te offeren als martelaar voor de ware islam. De jihad kreeg nog een extra urgentie. Want Qutb claimde niet alleen een interpretatie van de islam te geven, maar de waarheid te hebben ontdekt. Dat was een radicale claim die Hasan al-Banna, zelf weinig geïnteresseerd in religieuze doctrine, niet had durven maken. Uiteindelijk belichaamt Qutb de ultieme paradox van het islamisme: totale bevrijding leidt tot totale onderwerping; harmonie en vrede zijn gebaseerd op het zaaien van geweld en verderf. ${ }^{16}$ Het is deze strenge scheiding tussen goed en kwaad, vriend en vijand en de ultieme doctrinaire zekerheid waarop die berust die het jihadisme zo aantrekkelijk maken

Ook de pragmatische Moslim Broederschap erkende de doodlopende weg die Qutb was ingeslagen en heeft vanaf de jaren zeventig geprobeerd een antwoord te vinden op de 'totalitaire verleiding' van het jihadisme. Het antwoord was echter beperkt. De toenmalige algemene leider van de Moslim Broederschap schreef een boekje tegen Qutb, Predikers niet Rechters, waarin hij betoogde dat moslims het Woord mogen verkondigen, maar dat het niet aan hen is om te beslissen wie wel of geen goede moslims zijn. ${ }^{17}$ In de jaren tachtig, tijdens de liberale periode onder Mubarak, nam de Broederschap deel aan parlementaire verkiezingen en erkende ze het principe van 'partijpolitiek' en pluralisme, de grondwet en zelfs de gelijkheid van moslims en niet-moslims. Op een gegeven moment erkende de Broederschap zelfs het principe van 'volkssoevereiniteit'. Maar er bleven in de Egyptische politiek en bij waarnemers altijd twijfels bestaan in hoeverre de Moslim Broederschap 'om' was en een democratische organisatie was geworden. ${ }^{18}$

Tijdens de Arabische lente bleek dat de organisatie bereid was alles te doen om zelf aan de macht te komen en daarvoor afspraken met de militairen niet schuwde. Hoezeer de Moslim Broederschap een religieuze beweging was gebleven en de 'scheidingsmuren' van Walzer ontkende, bleek tijdens het presidentschap van Morsi van juni 2012 tot juli 2013. ${ }^{19}$ Politiek bedrijven bleek uiteindelijk meer dan moraliseren en het voeren van symboolpolitiek. De Broederschap had geen enkele oplossing voor de gigantische problemen waarvoor Egypte stond: falende economie, gebrek aan investeringen, toenemende armoede, jongerenproblemen, bevolkingsdruk, slecht onderwijs. Doordat de beweging veel te grote claims legt islam is de oplossing -, waren de verwachtingen zo groot dat ze daar op geen enkele manier aan kon voldoen.

Het echec van het politieke avontuur is niet alleen de schuld van het islamisme. Decennialange repressie heeft er ook voor gezorgd dat de islamitische beweging uit zelfbescherming zich niet tot een volledig politieke organisatie kon ontwikkelen. Tijdens Morsi werd ze ook op alle manieren tegengewerkt. Toch is ze ook zelf

16 Nog steeds een van de beste analyses van Sayyid Qutb is van R.L. Euben, Enemy in the Mirror: Islamic Fundamentalism and the Limits of Modern Rationalism. A Work of Comparative Political Theory, Princeton 1999.

17 B. Zollner, The Muslim Brotherhood: Hasan al-Hudaybi and Ideology, Londen 2009.

18 R. Meijer, 'The Majority Strategy of the Muslim Brotherhood', Die Orient 2013, 1, p. 21-30.

19 President Morsi werd in juni 2012 gekozen als kandidaat van de Moslim Broederschap. 
schuld aan het feit dat ze haar eigen liberale stromingen uitschakelde en geen brede coalitie tot stand bracht met liberale en seculiere partijen tegen de militairen. Ze kon ook niet beslissen of volkssoevereiniteit of Gods soevereiniteit de boventoon voerde. Diep in hun hart dachten haar leiders dat ze samenvielen; het was voor de leiders van de Moslim Broederschap ondenkbaar dat bevolking niet op een islamitische partij zou stemmen als de partij van God. ${ }^{20}$

\section{Salafisme}

Bij het salafisme, een religieuze beweging die doctrinair sterker is dan het islamisme, is de verwarring tussen theologie en politiek nog vele malen groter. Doel van het salafisme is louter theologisch: de zuivering van de islam van vreemde smetten, het herstel van het monotheïsme en het doel om uitsluitend een religieus leven te leiden. ${ }^{21}$ Het theologische doel daarachter is dat dit de enige manier is om het paradijs binnen te gaan; het politieke doel is dat alleen dan de islam weer superieur en oppermachtig kan worden. De moderne grondlegger van de beweging, Muhammad ibn Abd al-Wahhab (1703-1792), ging als rechtgeaarde religieuze hervormer alle on-islamitische uitwassen te lijf, zoals de aanbidding van heilige bomen en de graven van de metgezellen van de profeet. De rechtsgeleerden die veel later zijn leer uitbouwden, Muhammad Nasir al-Din al-Albani, Muhammad ibn al-Uthaymin, Ab al-Aziz Bin Baz, zijn pas in 1999 overleden, en daardoor is het een misvatting het salafisme als orthodox te noemen: afgezien van de achttiende-eeuwse grondlegger, is het in feite nog moderner dan de Moslim Broederschap. ${ }^{22}$ Belangrijker is dat de beweging haar succes dankt aan het politieke akkoord met de familie van Saoeds, sjeiks van een stam die in de Najd woonde. Zij had het vernuft het religieuze elan van de wahabieten te kanaliseren voor politieke doeleinden om gebied te veroveren en die te onderwerpen aan de strenge leer die ibn Abd al-Wahhab ontwikkelde. Maar het belangrijkste van het pact dat de nazaten van ibn Abd al-Wahhab maakten met de Saoeds is de arbeidsverdeling tussen geestelijken en politieke machthebbers. In ruil voor het monopolie op de politieke macht van de Saoeds, die de belastingen mochten innen, buitenlandse politiek mochten voeren en de interne orde handhaven, kreeg de familie van ibn Abd al-Wahhab het monopolie over de maatschappij, het onderwijs, de rechtspraak en de moraal. Deze overeenkomst was geheel in overeenstemming

20 Ik heb geen analyse van de Moslim Broederschap in Nederland opgenomen, omdat volgens Edwin Bakker die nauwelijks bestaat in Nederland. Zie zijn artikel 'The Public Image of the Muslim Brotherhood in the Netherlands', in: R. Meijer (red.), The Muslim Brotherhood in Europe, Londen 2012, p. 169-188.

21 R. Meijer (red.), Global Salafism. Islam's New Religious Movement, Londen 2009. Joas Wagemakers heeft inmiddels de beste inleiding geschreven tot de theologie van het salafisme: J. Wagemakers, Salafism in Jordan: Political Islam in a Queitist Community, Cambridge 2016.

22 Een van de interessantste academische onderzoeken die de laatste jaren is uitgekomen over het salafisme is van H. Lauzière, The Making of Salafism: Islamic Reform in the Twentieth Century, New York 2016. Hij stelt dat in de jaren zestig en zeventig van de vorige eeuw salafisme zich transformeerde tot een totalitaire ideologie. In die periode werd het salafisme 'an all-encompassing religious ideology comparable to Islamism' (p. 219). 
met het pact en de taakverdeling tussen geestelijken en heersers, zoals het bestond tijdens het Osmaanse Rijk en eerder, maar staat haaks op het kernidee van het wahabisme dat men zich moet onderwerpen aan Gods wetten en Gods soevereiniteit.

Het sluiten van een pragmatisch 'middeleeuws' pact in een moderne wereld zou later tot grote problemen leiden, die lange tijd verbloemd werden door de gigantische olie-inkomsten van Saoedi-Arabië. Enerzijds leidt het repressieve regime van de Saoeds tot gebrek aan burgerrechten en onderdrukking - Saoedi-Arabië geldt als een land dat meer dan welk ander land mensenrechten schendt. Anderzijds zou de hegemonie van de religieuze leer over de maatschappij leiden tot het wegvallen van de 'scheidingswanden' tussen religie, economie, maatschappij en wetenschap en de onderdrukking van zelfstandig en kritisch denken. Politiek had dit vergaande consequenties. Het overgrote deel van de bevolking was gezagsgetrouw en kon afgekocht worden door gratis voorzieningen, betaald uit olieinkomsten. Een kleine minderheid die wel politiseerde en vond dat de staat er niet alleen was om de orde te handhaven, greep naar de enige twee middelen die binnen deze verstikkende religieuze hegemonie mogelijk waren: of zij vond de politieke dimensie in de Moslim Broederschap en ontwikkelde het politieke salafisme, of zij vond via Sayyid Qutb het jihadisme en gaf daar een verdere theologische onderbouwing aan door het jihadi-salafisme te ontwikkelen. ${ }^{23}$

Welke vormen het salafisme ook aanneemt, vanuit het perspectief van politiek burgerschap vertonen ze onderling weinig verschil. Geen van drieën - de queïtistische, de politieke en de jihadistische - erkent de politiek als zelfstandig terrein en burgerschap als kritisch politieke opstelling. Het salafisme is een extreem voorbeeld van wat Luuk van Middelaar 'politicide' noemt, met paradoxaal genoeg enorme politieke gevolgen voor de omgeving. Het is een voorbeeld van identiteitspolitiek die werkelijke politieke kwesties 'absorbeert' en kanaliseert in religieuze rituelen, terminologie en rituele handelingen. De basishouding bij alle drie is die van intolerantie, niet alleen ten opzichte van niet-moslims, die vaak niet eens als 'mensen van het boek' worden gezien maar als 'ongelovigen', maar ook ten opzichte van moslims die niet tot de eigen stroming behoren. In beide gevallen is de leer van al-wala' wa-l-bara' (loyaliteit aan moslims en distantie van nietmoslims) van toepassing, die inhoudt dat je als salafist alleen mag omgaan met salafisten en dat je moslims die niet tot het salafisme behoren, ver moet houden en niet-moslims vijandig moet bejegenen. ${ }^{24}$ Hoewel deze houding niet tot jihadisme hoeft te leiden, zorgt het voor een sektarische inslag die tot uitsluiting van andersdenkenden leidt. De strikte regels waaraan salafisten zich moeten houden - vijf keer bidden per dag, strikte scheiding der seksen, volledige toewijding aan God, het niet doen van concessies aan de seculiere maatschappij -, leiden ook tot verdere maatschappelijke afzondering.

23 Het beste inleidende boek over jihadi-salafisme is van S. Maher, Salafi-Jahadism: The History of an Idea, Londen 2016. Daarin noemt hij deze stroming een 'total ideology' en een 'political religion' (p. 27). Maar hij koppelt het helemaal los van het salafisme als geheel, dat naar mijn mening ook veel trekken van een ideologie heeft.

24 Zie voor de Nederlandse inleiding in het onderwerp van het salafisme M. de Koning, J. Wagemakeres \& C. Becker, Salafisme, Almere 2014. Voor een Engelse inleiding zie Meijer 2009, p. 1-39. 
Deze grondhouding van het bewaren van religieuze zuiverheid is vol te houden zolang zij zich toelegt op de verspreiding van geloof onder moslims ( $d a^{\prime} w a$ ) en het verrichten van sociaal werk, en zich concentreert op onderwijs en gezondheidszorg. In een dictatuur zoals die van Mubarak in Egypte (1981-2011) werd het salafisme lange tijd gestimuleerd doordat deze beweging het onderwijs en sociale taken overnam van de staat en zich niet met de politiek bemoeide. Dit veranderde met het uitbreken van de Arabische Lente. De vraag diende zich aan of de salafisten zich moesten organiseren als partij en, zo ja, met welk doel. Uiteindelijk kwam de Nour-partij hieruit voort, op basis van het argument dat dit in het belang was van de islamitische gemeenschap (al-maslaha al-'amma). Zij bezorgde de Moslim Broederschap een serieuze competitie.

De tweede vraag was van fundamenteler aard en betrof de wijze waarop aan het politieke proces deel kon worden genomen. Moest dat gebaseerd zijn op het negatieve idee dat anders de 'seculieren en liberalen' de macht zouden overnemen, of moest dat op een positieve manier plaatsvinden door de economische en sociale belangen van het volk te dienen? Bij het oplossen van dit vraagstuk was ook de rol van de religieuze voormannen van de partij in het geding. Mochten zij de politieke lijn uitzetten en moest de partij geheel ondergeschikt worden gemaakt aan het verspreiden van het geloof - was het parlement zeg maar een moskee - of moest de partij ook politiek bedrijven en samenwerken met andere partijen en compromissen sluiten en in die zin echte politiek bedrijven door politieke vraagstukken te behandelen?

Het politieke avontuur van de Nour-partij pakte niet goed uit. Net als in Europa met de opkomst van de christendemocratische partijen ontstond er een flinke strijd tussen de 'geestelijken' enerzijds en de 'politici' anderzijds, die los wilden komen van de houdgreep waarin de geestelijken de partij hielden. Een jaar na de oprichting van de Nour-partij richtten de 'politici' een eigen partij, de Watan-partij, op, die uiteindelijk de kant van Morsi koos. De Nour-partij zou later de kant van Sisi kiezen. Het onvermogen van Morsi om compromissen te sluiten met seculieren en een grondwet tot stand te brengen waarin iedereen zich kon vinden, had al de basis gelegd voor het ingrijpen van de militairen.

Voor de Nour-partij lag de argumentatie anders. Ingewikkelde theologische vergelijkingen met de islamitische geschiedenis waarin Sisi vergeleken werd met veldheren uit de eerste eeuw na de dood van Mohammed, moesten aantonen dat Sisi's onderdrukking van de Moslim Broederschap legitiem was en dat Sisi het enige antwoord was op de dreigende fitna, ofwel de chaos en burgeroorlog die volgens de islamitische orthodoxie ten koste van alles voorkomen moet worden. Hoewel de Nour-partij tijdens de algemene verkiezingen in 2011-2012 26\% van de stemmen had gewonnen, werd ze bij de laatste verkiezingen van 2015 weggevaagd. Teleurgesteld in de politiek keerden veel salafisten terug naar het bedrijven van da'wa om de maatschappij te islamiseren. Ondertussen belandden de politieke évolués in de gevangenis of vluchtten het land uit. ${ }^{25}$ 


\section{Salafisme in Nederland}

Eenzelfde gecompliceerde relatie tussen religie en politiek doet zich voor bij het salafisme in Nederland. De spanning tussen het vooropstellen van religie als identiteitspolitiek enerzijds en het gebrek aan erkenning van het politieke proces als middel om sociale, culturele en politieke problemen aan te kaarten op basis van seculier burgerschap anderzijds, verlamt de beweging. Op zich biedt het principe van het 'algemeen belang' (al-maslaha al-'amma) van de islamitische gemeenschap wel uitkomst om actief burger te worden, maar doordat doctrine van het salafisme en de Nederlandse realiteit zo ver uiteen liggen, wordt dit al gauw een pragmatisme dat alleen gericht is op overleving en aanpassing, en in politieke termen zou men dit opportunisme kunnen noemen.

Verschillende prachtige dieptestudies geven een goed beeld van de diepe ambivalentie die uit deze spanning voortkomt. Zo roepen bekende salafistische predikers zoals Jneid Fawaz and Ahmed Salam hun aanhang op deel te nemen aan verkiezingen, maar alleen zolang die de 'belangen van moslims ten goede komen' en het 'partijprogramma geen haat (conflict) zaait'. ${ }^{26}$ Elders worden deelname aan het parlement en het maken van 'menselijke wetten' niet toegestaan. Daarentegen is zitting nemen in de gemeenteraad wel geoorloofd. ${ }^{27}$ Ook de soep van al-wala' walbara' wordt niet zo heet gegeten als de leer voorschrijft. Vriendschap met nietgelovigen wordt niet afgewezen, maar is pas aan te moedigen als het in dienst staat van 'uitnodigen naar de islam'. ${ }^{28}$

Apolitieke salafistische predikers wijzen eveneens takfier (excommuniceren) van jongeren af, omdat dat recht toebehoort aan sjeiks en het gevaar van verdeeldheid (fitna) dreigt. Om dezelfde reden bepleit sjeik Fawaz Jneid de acceptatie van de wetten van Nederland. Maar ook hier is religie weer het criterium. Ongehoorzaamheid aan de wetten kan alleen als moslims belemmerd worden in het uitoefenen van hun geloof, niet als hun rechten volgens de Nederlandse wet worden geschonden. ${ }^{29}$ Overigens spreken politieke salafisten in Nederland zich uit voor een gekozen politiek leiderschap, maar hoe dit moet gebeuren en volgens welke regels is net als in Egypte bij de Nour-partij, niet duidelijk. ${ }^{30}$ Bovendien is deze stellingname niet principieel, want, zoals Egypte laat zien, in geval van een crisis van de politieke orde is volgens de leer van het 'algemeen belang' een dictatuur acceptabel.

Uit deze voorbeelden blijkt het terugkerende probleem van de afwezigheid van een concept van politiek. Voortdurend vervallen salafisten in dezelfde fout religie en politiek met elkaar te verwarren door de zonde, 'nalatigheid' en 'overdrijving' in religie centraal te stellen en de politiek naar deze criteria te beoordelen. ${ }^{31} \mathrm{Dit}$

AIVD, Salafisme in Nederland: Een voorbijgaand fenomeen of een blijvende factor van betekenis, 2008, p. 46.

27 I. Roux, S. van Stiphout \& J. Tillie, Salafisme in Nederland: Aard, omvang en dreiging, Den Haag: WODC, Instituut voor Migratie en Etnische Studiën 2010, p. 98.

28 Idem, p. 93.

29 Idem, p. 95.

30 Idem, p. 95.

31 Idem, p. 76-79. 
blijkt ook uit de manier waarop salafisten burgerrechten invullen. Alleen wanneer hun eigen rechten op vrijheid van geloof worden geschonden, komen salafisten in het geweer. ${ }^{32}$

\section{Het modernisme en de erkenning van politiek en burgerrechten}

In Nederland wordt de liberale islam door liberale Nederlanders als oplossing gezien voor het salafisme, dat over het algemeen publiek diep gewantrouwd wordt en als wezensvreemd wordt gezien. Moslims die tot deze stroming behoren, zijn echter zodanig geseculariseerd dat ze mijlenver van de hoofdstromingen staan. ${ }^{33}$ Daarom is het belangrijk een onderscheid te maken tussen het islamitische liberalisme en het islamitische modernisme. Het voordeel van het islamitische modernisme is dat het wel teruggaat op islamitische bronnen en tegelijkertijd zich ook diepgaand bezighoudt met moderne vraagstukken en een concept heeft van politiek en burgerschap. Het modernisme in het Midden-Oosten is in de loop van de negentiende eeuw ontstaan als het antwoord op de (koloniale) invloed van het Westen, naast later het islamisme en het salafisme.

Net als het salafisme probeert het modernisme kracht te putten uit de terugkeer naar de bronnen van de islam. Maar in tegenstelling tot het huidige salafisme kenmerkt het modernisme zich door de erkenning van het rationalisme en de wetenschap en probeert het die niet door religie te laten absorberen (in die zin respecteert het modernisme de scheidingsmuren van Walzer). Wordt de inspiratiebron van de salafisten gevormd door de wetsgeleerde Ibn Taymiyya (1263-1326) en door Muhammad ibn 'Abd al-Wahhab, de basis voor het modernisme is de herontdekking van de werken van Taymiyya's tijdgenoot Abu Ishaq alShatibi (1320-1388). Het belang van al-Shatibi is dat hij stelt dat je niet de letterlijke tekst moet navolgen zoals de salafisten dat doen, maar dat je de 'algemene principes van de sharia' moet ontdekken.

Dit betekent een enorme bevrijding van de geest en het is dan ook niet verwonderlijk dat hedendaagse verlichte denktanks zoals het International Institute of Islamic Thought (IIIT) zich op de verspreiding van zijn ideeën richten. ${ }^{34}$ Dit concept stelde mensen in staat om vrij te denken en te discussiëren over de beginselen en uitganspunten van de islamitische regels. Want ook al was er een heilige tekst, het begrijpen van de tekst is altijd afhankelijk van feilbaar menselijke interpretatie. Dit wil niet zeggen dat het modernisme het bestaan van goddelijke tekst ontkent, maar het stelt wel dat niemand de absolute waarheid kan kennen en daardoor de waarheid in pacht heeft - een directe kritiek op de huidige salafisten en jihadi's.

Net als het liberalisme kent het modernisme grote verantwoordelijkheid toe aan het individu, het voeren van een open discussie en erkenning van het pluralisme. Individuele interpretatie (ijtihad) moet ervoor zorgen dat de betekenis van de

32 Idem, p. 97.

33 Voorbeelden zijn Maajid Nawaz uit Groot-Brittannië en Irshad Manji uit Canada.

34 Zie bijv. A. al-Raysuni, Imam al-Shatibi's Theory of the Higher Objectives and Intents of Islamic Law, Londen 2005. 
tekst aangepast wordt aan omstandigheden en dat jurisprudentie flexibel is. Het begrip 'algemeen belang' speelt daarbij een belangrijke rol, maar is bij modernisten minder conservatief en politiek minder opportunistisch dan bij het salafisme, omdat het opgenomen wordt in een poging een universele ethiek te onderbouwen die antwoord probeert te geven op moderne vragen. Hierdoor stelt het modernisme de mens centraal en schept het een islamitisch humanisme, in tegenstelling tot het salafisme, dat de tekst centraal stelt en de ratio daaraan onderschikt maakt. Hoewel de modernisten met het islamisme en het salafisme de centrale claim delen dat de islam een totaal systeem is, is de speelruimte bij de modernisten enorm veel groter en hanteren zij een meer realistische houding ten opzichte van het onderhandelen met de vaak vijandige omgeving. Dit geldt vooral voor het Midden-Oosten, waar het modernisme gezien wordt als een compromis aan het Westen. Voor Azië is dit minder het geval. Het gevolg is niet alleen een onbevreesde, onbekrompen interactie met het Westen, maar ook het creëren van een politieke ruimte, de acceptatie van gelijke rechten van man en vrouw en van moslim en niet-moslim, en de erkenning van de eigen dynamiek van de economie, wetenschap en politiek. Modernisten realiseren zich dat in een moderne, globaliserende wereld zowel de economie als de politiek niet meer onder te brengen is onder de hegemonie van religie. Religie kan volgens hen alleen invloed uitoefenen op deze terreinen door algemene ethische principes te ontwikkelen. Bovendien moeten die ook door het volk omarmd worden. Volgens hun radicale democratische houding kan politieke legitimatie niet ontleend worden aan God, maar wordt die gegeven door het volk. Zelfs de sharia kan alleen ingevoerd worden als een grote meerderheid van het volk daarmee instemt en de rechten van minderheden gewaarborgd zijn. Het is geen heiligschennis daarover te stemmen, want het volk is soeverein.

Ten slotte willen modernisten de vrijheid van menselijk handelen zo groot mogelijk maken. ${ }^{35}$ Proberen salafisten zo veel mogelijk aspecten van het leven te legitimeren met regels van God door alle menselijke gedragingen te beschouwen als 'ibadat (rituelen voor het aanbidden van God), modernisten proberen de interactie tussen mensen zo vrij mogelijk te maken en verantwoordelijkheid van vrij menselijk handelen te vergroten. Hiermee wordt religie van een nauwgezette handleiding van het dagelijks handelen verheven tot een algemeen ethische leidraad voor praktisch handelen. Met deze herwonnen ruimte wordt pluralisme, democratie en burgerschap steviger verankerd. Grondwetten zijn niet een noodzakelijk kwaad die gebruikt kunnen worden om de islamitische boodschap te verspreiden, maar een fundamentele verworvenheid van burgers. Deelname aan de politiek wordt een plicht.

35 De beste inleiding op het islamitisch modernisme is C. Kurzman, 'Introduction: Liberal Islam and its Liberal Context', in: C. Kurzman (red.), Modernist Islam, 1840-1940: A Sourcebook, Oxford 2002, p. 3-26. 


\section{Enkele modernistische denkers}

Deze stappen naar bevrijding uit de verstikkende omklemming van de tekst en de defensieve en apologetische lijn van het salafisme en de Moslim Broederschap zijn een lang proces geweest. Ik zal aan de hand van verschillende denkers duidelijk maken hoe dit proces verlopen is.

De eerste modernist in de Arabische wereld die gezien wordt als de grondlegger van het modernisme is de Egyptenaar Muhammad 'Abduh (1849-1905). Bij hem houden een conservatieve politieke houding en opening naar de wetenschap elkaar nog in evenwicht. Weliswaar gebruikt hij veelvuldig de begrippen 'algemeen belang' en 'rationaliteit', maar gaat hij uit van een vastgestelde goddelijke orde die alleen de elite kan ontwaren. In Egypte na de opkomst van de Moslim Broederschap verschuift het modernisme naar de Maghreb, met als belangrijke figuren Allal al-Fasi (1910-1975) en de Algerijn Malek Bennabi (1905-1973). Met name in Azië komt het modernisme op. Voorbeelden zijn Muhammad Iqbal (1877-1938) en later Fazlur Rahman (1919-1988). Maar het komt toch weer terug in het Midden-Oosten wanneer duidelijk wordt dat de strategie en de rigiditeit van de Moslim Broederschap geen opening bieden.

Een goed voorbeeld van iemand die onbeschroomd westerse begrippen gebruikt en zegt dat dit geen gevaar met zich meebrengt zolang ze overeenkomen met de islam en een verbetering voor moslims betekenen, is sjeik Yusuf al-Qaradawi (1926). Hoewel hij lid was van de Moslim Broederschap, heeft hij zich sinds 1962 gevestigd in Qatar en is hij een instituut op zich geworden. In Europa speelt hij een belangrijke rol in de European Fatwa and Research Council, waar hij zich bezighoudt met moslims als minderheden in zijn jurisprudentie van minderheden (fiqh al-'aqalliyyat). In het Midden-Oosten wordt hij vaak gezien als een progressieve kracht en houdt hij zich bezig met algemene politieke vraagstukken. Het grote verschil met de salafisten is dat hij termen als democratie, mensenrechten, volkssoevereiniteit, verkiezingen, gelijke rechten van man en vrouw en van moslim en niet-moslim, en burgerschap niet schuwt. Veelvuldig maakt hij ook gebruik van een begrip als 'algemeen belang' en de techniek van de 'jurisprudentie van de afweging' (fiqh al-tawazunat), waarbij je je op rationale gronden bij iedere handeling moet afvragen of die ten goede of ten nadele van de gemeenschap uitvalt. ${ }^{36}$ Qaradawi is voorvechter van een 'burgerlijke staat' in plaats van een 'religieuze staat'. ${ }^{37}$ Dit omdat geestelijken volgens hem te rigide zijn en te veel naar de tekst kijken en niet het algemene belang voor ogen houden. Andere manieren om de invloed van religie te kanaliseren is door in de grondwet vast te leggen dat partijen geen religieuze waarheidsclaims mogen maken en verplicht zijn een partijprogramma op te stellen waarin ze duidelijk maken wat hun ideeën zijn over politiek, economie en sociale aangelegenheden. ${ }^{38}$ Verder vindt hij dat machthebbers Islamic Movement in the Coming Phase, Caïro 1992, p. 42-3. 
verantwoording moeten afleggen aan het volk en dat zij altijd kunnen worden afgezet en dat dit weinig met fitna te maken heeft.

Ondanks deze vooruitstrevende meningen is het duidelijk dat al-Qaradawi binnen het algemene kader van de Moslim Broederschap blijft. In veel van zijn geschriften heb je het ongemakkelijke gevoel dat wat hij geeft met de ene hand, terugneemt met de andere. In laatste instantie is democratie bij hem toch ondergeschikt aan de islam, en de politiek heeft bij hem geen onafhankelijke bewegingsruimte. Dit bleek onder meer toen hij Morsi tot het einde steunde. Hoewel hij openlijk stelde dat Morsi zijn legitimiteit ontleende aan het volk en hij daarom niet afgezet kon worden door de militairen, gaf hij de indruk dat de Moslim Broederschap de partij van God (Hizbollah) was en haar legitimiteit dus niet zozeer ontleende aan de stembus maar aan God. ${ }^{39}$

De jongere generatie van modernisten gaat daarentegen wel verder in haar zienswijze over islam en politiek. Een goed voorbeeld is Abu Ala Madi, de voormalige leider van de in 1996 opgerichte Egyptische Wasat-partij, die plompverloren verklaart dat zijn partij een 'civiele' partij is die zich zal houden aan politieke regels en geen 'religieuze' partij is die religie verspreidt - zoals bij de salafistische partijen. Hij stelt ook dat de partij gebaseerd is op volkssoevereiniteit en dat het volk zelf zal beslissen wat het 'algemene belang' is. Hij verklaart dat kopten, de Egyptische christelijke minderheid, gelijke rechten hebben als volwaardige burgers en daardoor toegang hebben tot alle beroepen, net als moslims. ${ }^{40}$

De Soedanees Abdelwahhab El-Affendi zit op dezelfde lijn en vraagt zich openlijk af waarom de islamitische beweging vasthoudt aan een islamitische staat terwijl iedereen weet dat de islam een flinterdunne staatstheorie heeft ${ }^{41}$ en zich vooral heeft beziggehouden met het karakter van de heerser en niet met het voortbrengen van een rechtvaardig en werkbaar politiek systeem. ${ }^{42}$ Als voormalig aanhanger van Hasan al-Turabi's NIF, die tijdens de burgeroorlog met Zuid-Soedan het land in de afgrond heeft gestort, kent El-Affendi als geen ander de zwakheden van het islamisme. Als een van de weinigen durft hij te stellen dat het islamitische utopisch politieke denken van veel islamisten tot veel ellende heeft geleid.

Dat het modernisme zich niet beperkt tot intellectuelen, maar zich uitstrekt tot hele bewegingen bewijst Rachid Ghannouchi, de leider van de Tunesische Ennahda-partij, die na de verkiezingen van 2011 de premier leverde van de eerste democratisch gekozen regering. In een bijzonder liberaal document stelt hij dat het algemeen belang gelijkgesteld kan worden aan democratie en dat het grote probleem in het Midden-Oosten niet het gebrek aan religie is, maar een gebrek aan democratie. ${ }^{43}$ Het algemeen belang schrijft dan ook voor dat islamitische partijen te allen tijde moeten samenwerken met andere partijen, ook al zijn die secu-

39 R. Meijer, 'The Political, Politics and the Citizenship in Modern Islam'.

40 A. al-'Ala Madi, Mas 'ala al-qibtiyya, wa-l-shari ' $a$, wa-l-al-sahwa al-islamiyya [De koptische zaak, de islamitische wet en het islamitische ontwaken], Caïro 2007.

41 Zie ook M. Berger, 'Kalifaat en de islamitische staat', Tijdschrift voor Religie, Recht en Beleid 2007, 1.

42 A. El-Affendi, Who Needs an Islamic State?, Londen 2008.

43 R. Ghannouchi, 'Participation in Non-Islamic Government', in: C. Kurzman (red.), Liberal Islam: A Source Book, Oxford 1998, p. 89-95. 
lier. Uiteindelijk was hij zelfs bereid 'gelijkheid' van man en vrouw in de Tunesische grondwet te laten opnemen.

Ten slotte moet de filosoof en theoloog Jasser Auda genoemd worden. Hij heeft een moderne onderbouwing gevonden in het concept van de 'algemene principes van de sharia' van de middeleeuwse jurist al-Shatibi's en dat omgewerkt tot een moderne systeemtheorie. ${ }^{44}$ Bij het lezen van zijn geschriften krijg je meteen het gevoel dat hij een algemeen geldende islamitische ethiek probeert te vinden die ook niet-moslims aanspreekt. Hij spreekt dan ook niet meer van een 'totaal systeem', maar in zijn poging het dagelijkse leven te 'ontheiligen' wordt islam een Weltanschauung. ${ }^{45}$ Niet toevallig schaarde hij zich onomwonden achter de Egyptische demonstranten tijdens de Arabische Lente en hamerde hij op hun sociale, politieke en religieuze rechten. ${ }^{46}$

\section{Islamitisch modernisme in Nederland}

In Nederland is het modernisme zwak vertegenwoordigd. Het salafisme is overheersend onder Marokkaanse Nederlanders, en de debatten tussen modernisten en salafisten zijn op één hand te tellen. Desondanks zijn er interessante en zelfbewuste modernisten te vinden, zoals Mohamed Ajouaou, die in veel opzichten de weg voorbereidt voor een 'rekkelijke' interpretatie van de islam. Hij ziet 'rekkelijkheid als een hermeneutische activiteit, die gericht is op het verkennen van de bestaande geloofs- en handelingsruimte die niet wordt benut, het ontdekken van nieuwe verbanden, het opheffen van allerlei schijntegenstellingen en dilemma's, en van de onnodige beperkingen die aan het geloof werden en nog steeds worden toegeschreven'. ${ }^{47}$ Daarbij richt hij zich op het vermijden van 'benauwdheid' en het bevorderen van vrijheid van handelen van het individu. Opmerkingen als 'veel vragen behoeven immers geen religieus antwoord, maar een flinke dosis gezond verstand'48 duiden op het scheppen van ruimte om zelfstandig na te denken. Volgens hem opent de 'ont-theocratisering van dit religieus kader (de politiek) en van het aanpassen aan het (seculiere) openbare karakter van het leven' 49 de weg naar verpolitiseren van kwesties die als zodanig beoordeeld moeten worden en buiten het religieuze domein horen te liggen.

Door zijn hele werk strooit hij met termen als burgerschap, verantwoordelijkheid, gezond verstand en algemeen belang. Over dat laatste zegt hij: '[O]p basis hiervan is elke daad acceptabel en aanbevolen, als daarmee een bijdrage wordt geleverd aan het maatschappelijk belang.' Als voorbeeld noemt hij orgaandonatie: 'Verondersteld wordt dat het doneren van een orgaan tot een betere maatschappij, tot

J. Auda, Maqasid al-Shariah as Philosophy of Islamic Law, Londen 2008.

Idem, p. 104.

J. Auda, Sharia and Politics: Questions for Post-Revolutionary Phase, https://cscsebook.files. wordpress.com/2016/12/sharia-and-politics.pdf.

M. Ajouaou, De moslim die ik ben, Amsterdam 2006, p. 17.

Idem, p. 22.

Idem, p. 24. 
betere sociale verhoudingen, tot een beter mens leidt, en dan is dat zeker toegestaan. ${ }^{50}$

\section{Conclusie}

In tegenstelling tot wat meestal wordt beweerd door islamisten - en wat nagepraat wordt door critici van de islam - hebben islam en politiek altijd een complexe verhouding tot elkaar gehad en hebben islamitische rijken vanaf de dood van de profeet Mohammed een zekere vorm van secularisering gekend die nog versterkt werd aan het einde van de negentiende eeuw onder Europese invloed. Deze vorm van secularisering bestond uit een arbeidsverdeling tussen heerser en geestelijke, waarbij de eerste politieke en militaire macht uitoefent en de tweede een moreel gezag uitoefenen over de maatschappij. Na de afschaffing van het kalifaat in 1924 werd de relatie opnieuw ter discussie gesteld. In de strijd tegen het kolonialisme werd het ideaal van eenheid van religie en staat verheven tot een utopisch alternatief voor verdere marginalisering van de sharia.

De Moslim Broederschap is de eerste moderne politiek ideologische beweging die begon met het ontkennen van de scheidingsmuren tussen religie, politiek en wetenschap en het poneren van het concept islam als 'totaal systeem'. Het gevolg was het wegvallen van de politiek als zelfstandig veld en de burger als politieke participant. De logische volgende stap was het jihadisme van Sayyid Qutb, in wiens geschriften de politiek volledig is 'geabsorbeerd' door religie. Het salafisme grijpt weer terug op de klassieke arbeidsverdeling tussen politiek en geestelijk gezag. Maar omdat bij het salafisme de zuivering van de islam vooropstaat en weinig nagedacht wordt over praktische politiek, is de politiek nog minder ontwikkeld dan bij het islamisme van de Broederschap. De meest extreme uitdrukking van het islamitische utopisme is het jihadisme.

Voor Nederland en andere westerse landen heeft het ontbreken van de erkenning van een zelfstandig politiek domein bij deze stromingen grote gevolgen. Ten eerste is het concept van politiek als concept niet uitgewerkt, waardoor ook het vermogen om niet in absolutistische termen en pragmatische oplossingen te denken zwak is ontwikkeld. Ten tweede zijn burgerschap en politieke participatie lange tijd onderontwikkeld gebleven, en voor zover die wel werden ontwikkeld namen die een opportunistisch karakter aan - louter het belang van de eigen gemeenschap dienend. Ten derde heb ik geprobeerd aan te tonen dat dit niet direct met de islam te maken heeft, want de modernistische stroming erkent wel degelijk de politiek als zelfstandig domein en het belang van het concept van burgerschap. De fundamenten hiervoor worden gelegd door algemene ethische principes te distilleren uit de islamitische wet en tot een concept te komen van het 'algemeen belang', dat veel verder gaat dan de eigen groepering en zich uitstrekt tot de gehele (niet-islamitische) maatschappij.

Het concept van algemeen belang is daarom bij het modernisme niet alleen pragmatisch en opportunistisch, maar ook principieel. Het legt het fundament voor de 
acceptatie van de rechtsstaat. Dit wil niet zeggen dat salafisten en islamisten deze weg niet kunnen afleggen. De Nour-partij in Egypte maakt duidelijk dat zelfs binnen een salafistische partij 'politici' kunnen opstaan die zich verzetten tegen de macht van de geestelijken en erkennen dat de politiek haar eigen logica heeft. Maar het doordenken van de consequenties voor de basisideeën van het salafisme als transparantie van de tekst, ontkenning van religieus, cultureel en politiek pluralisme, loyaliteit ten opzichte van moslims en afstand houden (discriminatie) ten opzichte van niet-moslims maken deze omslag moeilijk. In welke mate ook salafisten in Nederland deze transformatie doormaken is niet helemaal duidelijk. Veel van het onderzoek naar de ideeën van salafisten in Nederland is tamelijk verouderd. Het zou de moeite lonen een linguïstisch politiek onderzoek te doen naar de verandering in hun terminologie en houding om nauwkeurig te onderzoeken hoe hun discours veranderd is. 